\title{
The inhibitory CD200R is differentially expressed on human and mouse $\mathrm{T}$ and $\mathrm{B}$ lymphocytes
}

\author{
Eva S.K. Rijkers ${ }^{a}$, Talitha de Ruiter ${ }^{a}$, Ajoeb Baridi ${ }^{a}$, Henrike Veninga ${ }^{b}$, \\ Robert M. Hoek ${ }^{\mathrm{b}}$, Linde Meyaard ${ }^{\mathrm{a}, *}$ \\ a Department of Immunology, UMC Utrecht, Utrecht, The Netherlands \\ ${ }^{\mathrm{b}}$ Department of Experimental Immunology, University Medical Centre, Amsterdam, The Netherlands
}

Received 4 May 2007; received in revised form 13 July 2007; accepted 18 July 2007

Available online 21 August 2007

\begin{abstract}
To ensure an adequate response against pathogens and prevent unwanted self-reactivity, immune cells need to functionally express both activating and inhibitory receptors. CD200R is an inhibitory receptor mainly expressed on myeloid cells that down-modulates cellular activation both in vivo and in vitro. Although previously mainly studied as a regulator of myeloid function, we now show that CD200R is differentially expressed on human and mouse T-cell subsets. In both species, $\mathrm{CD} 4^{+} \mathrm{T}$ cells express higher amounts of CD200R than CD8 ${ }^{+} \mathrm{T}$ cells, and memory cells express higher amounts of CD200R than naïve or effector cells. CD200R expression is up-regulated on both $\mathrm{CD}^{+}$and $\mathrm{CD}^{+} \mathrm{T}^{+}$cells after stimulation in vitro. Furthermore, we show CD200R expression on human and mouse B cells. In human tonsils, CD200R is differentially expressed on B cells, with high expression on memory cells and plasmablasts. Mice lacking the ligand for CD200R, CD200-1- mice, do not show abnormal composition of the lymphocyte compartment and have normal B cell responses to antigenic challenge. Although the functional implications remain to be elucidated, the expression of CD200R on lymphocytes suggests a much broader role for CD200R-mediated immune regulation than previously anticipated. (C) 2007 Elsevier Ltd. All rights reserved.
\end{abstract}

Keywords: Immune regulation; CD200R; Lymphocytes; Inhibitory receptors

\section{Introduction}

The equilibrium between inhibition and activation of the immune system is delicate. Too much inhibition may result in immune deficiency, whereas too much activation could cause damage to the host. Therefore, every immune cell expresses inhibitory receptors to balance signals from activating receptors (Ravetch and Lanier, 2000).

Most immune cells express multiple inhibitory receptors. The function of these inhibitory receptors is not redundant, as has been shown by studies using mice deficient for several Bcell inhibitory receptors (Pritchard and Smith, 2003). Despite the fact that expression levels may be low, inhibitory immune receptors play an important role in maintaining immune homeostasis since absence of inhibitory immune receptors results in increased activation of immune cells, in some cases leading to

\footnotetext{
* Corresponding author.

E-mail address: 1.meyaard@umcutrecht.nl (L. Meyaard).
}

spontaneous auto-immunity (Bolland and Ravetch, 2000; Takai et al., 1996).

CD200R is an inhibitory immune receptor that binds to CD200. Both molecules are members of the Ig superfamily and contain two Ig-like domains. CD200 is widely expressed and has a short intracellular tail which does not contain signalling motifs, whereas CD200R has a longer intracellular tail that contains three tyrosines, one of which is located in an NPXY motif (Wright et al., 2000). However, CD200R does not contain the common immunoreceptor tyrosine-based inhibition motifs (ITIMs) and has been described to regulate cellular activation via recruitment of the adaptor molecules Dok-1 and Dok-2 to the tyrosines in its intracellular tail (Zhang et al., 2004; Zhang and Phillips, 2005).

CD200R has been reported to be mainly expressed on myeloid cells such as monocytes, macrophages, granulocytes and dendritic cells and is an important signalling molecule in the inhibition of myeloid responses to challenge (Wright et al., 2000, 2003). In vitro studies have shown that ligation of CD200R results in decreased degranulation and cytokine secretion by 
mast cells, monocytes and macrophages (Jenmalm et al., 2006; Cherwinski et al., 2005). In addition, deletion of the CD200 gene in mice results in enhanced susceptibility to auto-immune disease and increased myeloid response to inflammation (Hoek et al., 2000). Lack of CD200R signalling in CD200-/- mice was found to result in enhanced Th2 switching upon induction of tolerance, implicating a role for CD200R signalling in regulating Th2 cell function (Taylor et al., 2005). Moreover, expression of CD200R on lymphocyte subsets was shown, suggesting a broader role for CD200R in the regulation of immune cells (Wright et al., 2003; Rosenblum et al., 2005). Indeed, CD3-induced proliferation and cytokine secretion by dendritic epidermal T cells can be inhibited by crosslinking of CD200R on the surface of these cells (Rosenblum et al., 2005).

Here, we study the expression of the inhibitory CD200R on different lymphocyte subsets in human and mouse peripheral blood and lymphoid organs to elucidate the potential role of CD200R expression on these cells. Most surprisingly, we report clear CD200R expression on B cells in both species. Although the functional role of CD200R expression on lymphocyte subsets remains to be elucidated, its regulated expression pattern on lymphocytes suggests a broad role of CD200R in the regulation of immune function.

\section{Materials and methods}

\subsection{Mice}

Wild type C57BL/6J and CD200 ${ }^{-1-}$ mice were bred at the Amsterdam Medical Centre animal facility. For some experiments, wild type C57BL/6J mice were obtained from Charles River (France). All animals were used as approved by the Utrecht and Amsterdam University animal ethics committees.

For antigen challenge, mice received a single dose of either $10 \mu \mathrm{g}$ TNP-Ficoll (T-cell-independent (TI) antigen) or $25 \mu \mathrm{g}$ TNP-KLH (T-cell-dependent (TD) antigen) in $100 \mu \mathrm{l} \mathrm{PBS}$ by intravenous (i.v.) injection in the lateral tail vein. Serum was collected weekly, until 4 weeks after immunization, from blood obtained via the tail vein. Anti-TNP antibody titres were assessed by an isotype-specific ELISA.

\subsection{Cells}

Mouse spleens and inguinal, axillary and brachial lymph nodes were strained through nylon sieves to obtain single cell suspensions, after which erythrocytes were lysed. Human peripheral blood leukocytes (PBL) were isolated from peripheral blood from healthy volunteers by density gradient centrifugation on Ficoll-Paque combined with Histopaque. Human peripheral blood mononuclear cells (PBMC) were isolated by centrifugation on Ficoll-Paque. Human tonsils were rest material from adenotomies and/or tonsillectomies. Tonsils were minced and leukocytes were washed out to obtain single cell suspensions. All cells were resuspended in RPMI 1640 medium (Gibco BRL, Life Technologies, Paisley, UK) supplemented with $10 \%$ heatinactivated foetal calf serum (Integro, Dieren, The Netherlands), penicillin and streptomycin (Gibco).

\section{3. $T$ cell stimulation in vitro}

A 24-well plate was coated with $1 \mu \mathrm{g} / \mathrm{ml}$ anti-CD3 (OKT3, Janssen Cilag, Tilburg, The Netherlands) and/or $5 \mu \mathrm{g} / \mathrm{ml}$ antiCD28 (15E8, kindly provided by Dr. R. van Lier) in a final volume of $200 \mu \mathrm{PBS}$ for $2 \mathrm{~h}$ at $37^{\circ} \mathrm{C} .1 .5 \times 10^{6} \mathrm{PBMC} / \mathrm{ml}$ were cultured for 4 days in the coated wells.

\subsection{Flow cytometry}

Antibodies against human CD3, CD4, CD8, CD25, CD27, CD45RO, CD19, CD38, IgD, CD11b, CD56 and mouse CD3, CD4, CD8, CD44, CD62L, CD25, CD69, DX5, NK1.1, B220, Gr-1, CD11b were obtained from Beckton Dickinson Biosciences (San Diego, United States). Antibodies against human IgG and IgM were obtained from DAKO (Glostrup, Denmark) and anti-human IgA antibodies were obtained from Jackson Bioscience (West Grove, United States). Antibodies against human and mouse CD200 and CD200R were obtained from Serotec (Kidlington, Oxford, UK), as was anti-mouse F4/80. Cells were incubated with antibodies on ice for $30 \mathrm{~min}$. A FACSCalibur with BD CellQuest software (BD Pharmingen) was used for acquisition and analysis. For quantification of CD200R expression, MFI of isotype control stainings, although low in all cases, was subtracted from MFI values of CD200R stainings.

\subsection{Mouse antibody ELISA}

Flat-bottom 96-well MAXIsorp plates (Nunc, Roskilde, Denmark) were coated with $50 \mu \mathrm{l}$ of $1 \mu \mathrm{g} / \mathrm{ml}$ isotype-specific anti-immunoglobulin antibodies in PBS and incubated overnight at $4{ }^{\circ} \mathrm{C}$. Plates were washed with PBS and blocked with $3 \%$ BSA in PBS for $1 \mathrm{~h}$ at room temperature. Sera were added in three-fold dilutions starting at 1:150 in a total volume of $50 \mu$ l. After incubation for $2 \mathrm{~h}$ at room temperature, plates were washed and $50 \mu \mathrm{l}$ biotinylated isotype-specific antibodies $(0.1 \mu \mathrm{g} / \mathrm{ml}$ in PBS) were added. Plates were incubated for $1 \mathrm{~h}$ at room temperature and antibodies were detected by the addition of poly-streptavidin-HRP. Plates were developed with ABTS according to the manufacturer's protocol.

Anti-TNP antibody titres were assessed by an isotypespecific ELISA. MAXIsorp plates were coated with $50 \mu \mathrm{l}$ of $1 \mu \mathrm{g} / \mathrm{ml} \mathrm{TNP}-\mathrm{BSA}$ in $0.1 \mathrm{M}$ carbonate buffer ( $\mathrm{pH}$ 9.7) overnight at $4{ }^{\circ} \mathrm{C}$. Plates were blocked by incubating with $2 \%$ non-fat dry milk (NFDM) in PBS for $1 \mathrm{~h}$, and washed with PBS-T. Sera were applied in a three-fold dilution series starting at 1:100 and ending at $1: 24,300$ and plates were incubated overnight at $4{ }^{\circ} \mathrm{C}$. After washing plates were incubated with $1 \mu \mathrm{g} / \mathrm{ml}$ biotinylated $\mathrm{Ig}$ isotype-specific antibody in $2 \%$ NFDM, washed again and incubated with streptavidin-AP conjugate. Following a final wash, the plates were developed in $100 \mu \mathrm{l}$ pNPP buffer (Sigma, St. Louis, United States) according to the manufacturer's protocol.

\subsection{Statistical analyses}

Nonparametric statistical tests were used since the data were not normally distributed. Differences between the groups were 
analysed using Mann-Whitney tests. A $p$-value smaller than 0.05 was considered statistically significant. All statistical analyses were performed using SPSS 12.0 (SPSS Inc., Chicago, United States).

\section{Results}

\subsection{CD200R is expressed on human and mouse lymphocytes}

To study the distribution of CD200R, we stained human PBL with an $\alpha$ CD200R antibody (Fig. 1A). As expected, CD200R was highly expressed on $\mathrm{CD} 11 \mathrm{~b}^{+}$myeloid cells. In agreement with previous results, CD200R was also expressed on $\mathrm{CD}^{+}$ $\mathrm{T}$ cells (Wright et al., 2003), and reproducibly at low levels on $\mathrm{CD} 3{ }^{-} \mathrm{CD}^{2} 6^{+} \mathrm{NK}$ cells. Unexpectedly, we also found clear expression of $\mathrm{CD} 200 \mathrm{R}$ on peripheral $\mathrm{CD}^{-} \mathrm{CD} 19^{+} \mathrm{B}$ cells. To our knowledge, this is the first time that a clear expression of CD200R on B cells is reported.
To analyse the CD200R expression on mouse leukocytes, C57BL/6J spleen cells were harvested and flow cytometric analysis showed that highest CD200R expression was found on

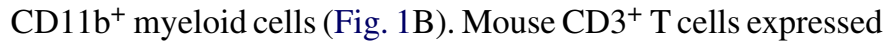
low but detectable levels of CD200R. Interestingly, CD200R was expressed in significant levels on mouse $\mathrm{CD} 3^{-} \mathrm{DX} 5^{+} \mathrm{NK} 1.1^{+}$ NK cells. Mouse splenic B220 $0^{+}$B cells, like human peripheral blood B cells, expressed high levels of CD200R. Furthermore, on mouse blood and lymph node cells we found similar expression patterns (data not shown).

\subsection{CD200R is differentially expressed on T-cell subsets}

To predict the potential capacity of CD200R to regulate different T-cell subsets, we studied CD200R expression on these populations. In human samples, subsets were determined by staining with $\mathrm{CD} 27$ and $\mathrm{CD} 45 \mathrm{RO}$ as follows: $\mathrm{CD} 27^{+} \mathrm{CD} 45 \mathrm{RO}$, naïve $(\mathrm{N}) \mathrm{T}$ cells; $\mathrm{CD} 27^{+} \mathrm{CD} 45 \mathrm{RO}^{+}$, central memory $(\mathrm{CM}) \mathrm{T}$ cells; $\mathrm{CD} 27^{-} \mathrm{CD}^{2} 5 \mathrm{RO}^{+}$, effector memory (EM) $\mathrm{T}$ cells and

\section{(A) Human}
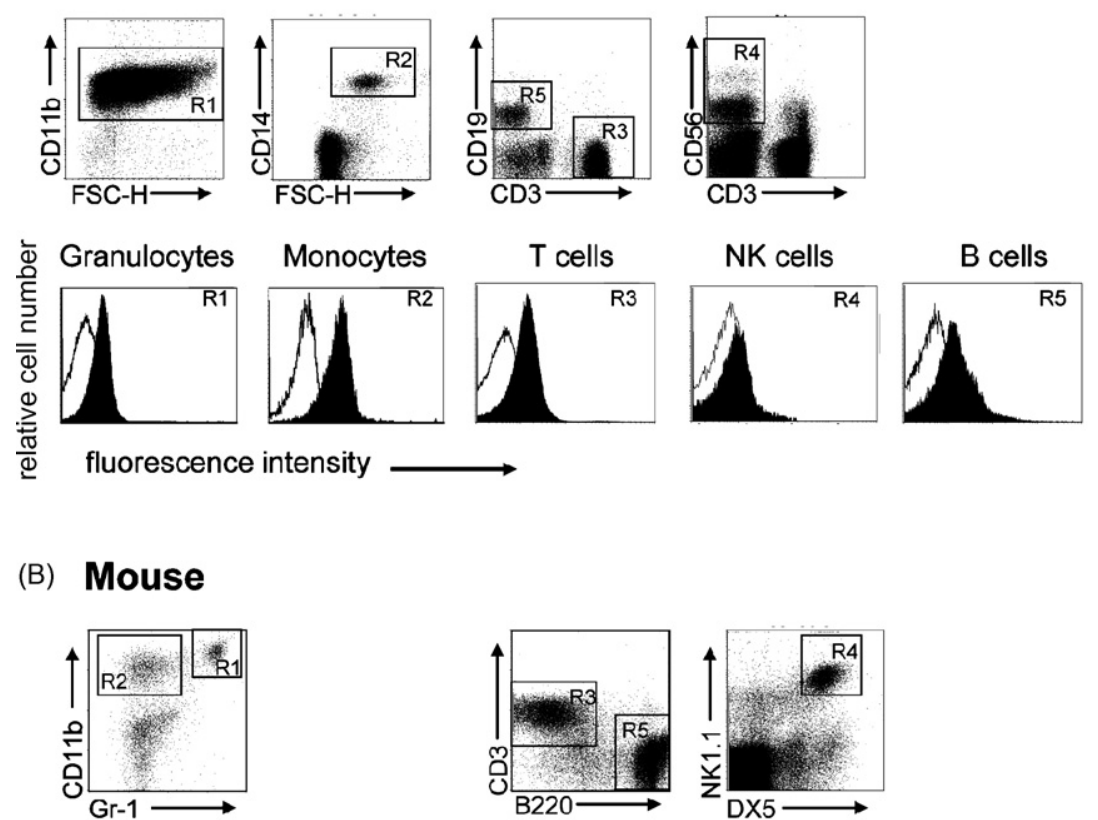

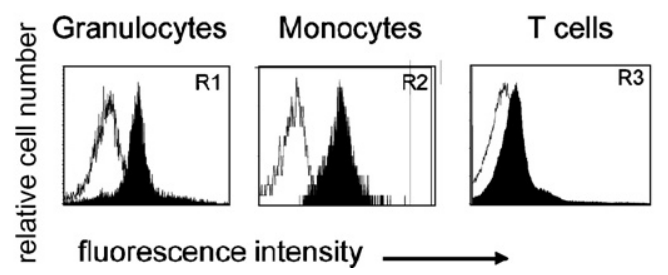

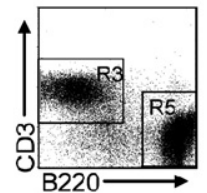
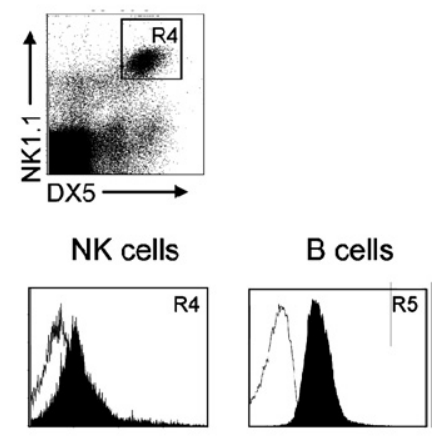

Fig. 1. CD200R is expressed on human and mouse lymphocytes. (A) Human peripheral blood leukocytes were stained using anti-CD11b, -CD14, -CD3, -CD56 and -CD19. Top panels show gating used to determine CD200R expression per cell type, as shown in the lower histogram panels. Granulocytes were identified based on forward/sideward scatter and $\mathrm{CD} 11 \mathrm{~b}^{+}$staining, monocytes were identified based on forward/sideward scatter and $\mathrm{CD} 14^{+}$staining, $\mathrm{CD}^{+}$cells were identified as $\mathrm{T}$ cells, $\mathrm{NK}$ cells were $\mathrm{CD} 3^{-} \mathrm{CD} 56^{+}$and $\mathrm{B}$ cells were $\mathrm{CD}^{-} \mathrm{CD} 19^{+}$. Open histograms represent isotype control staining, filled histograms represent $\mathrm{CD} 200 \mathrm{R}$ staining. Data shown are representative for six different donors analysed in three independent experiments. (B) Spleen cells from wt C57BL/6J mice were isolated by forcing them through nylon cell strainers and were stained using anti-Gr-1, -CD11b, -CD3, -DX5, -NK1.1, and -B220. Top panels show gating used to determine CD200R expression per cell type, as shown in the lower histogram panels. Granulocytes were identified based on forward/sideward scatter and CD11 $\mathrm{b}^{+} \mathrm{Gr}-1^{+}$staining, monocytes were $\mathrm{CD} 11 \mathrm{~b}^{+} \mathrm{Gr}-1^{-}, \mathrm{T}$ cells were $\mathrm{CD}^{+}$, NK cells were $\mathrm{CD} 3^{-} \mathrm{NK} 1.1^{+} \mathrm{DX} 5^{+}$and B cells were $\mathrm{CD} 3^{-} \mathrm{B} 220^{+}$. Open histograms represent isotype control staining, filled histograms represent CD200R staining. Data shown are representative of three independent experiments. 
(A)
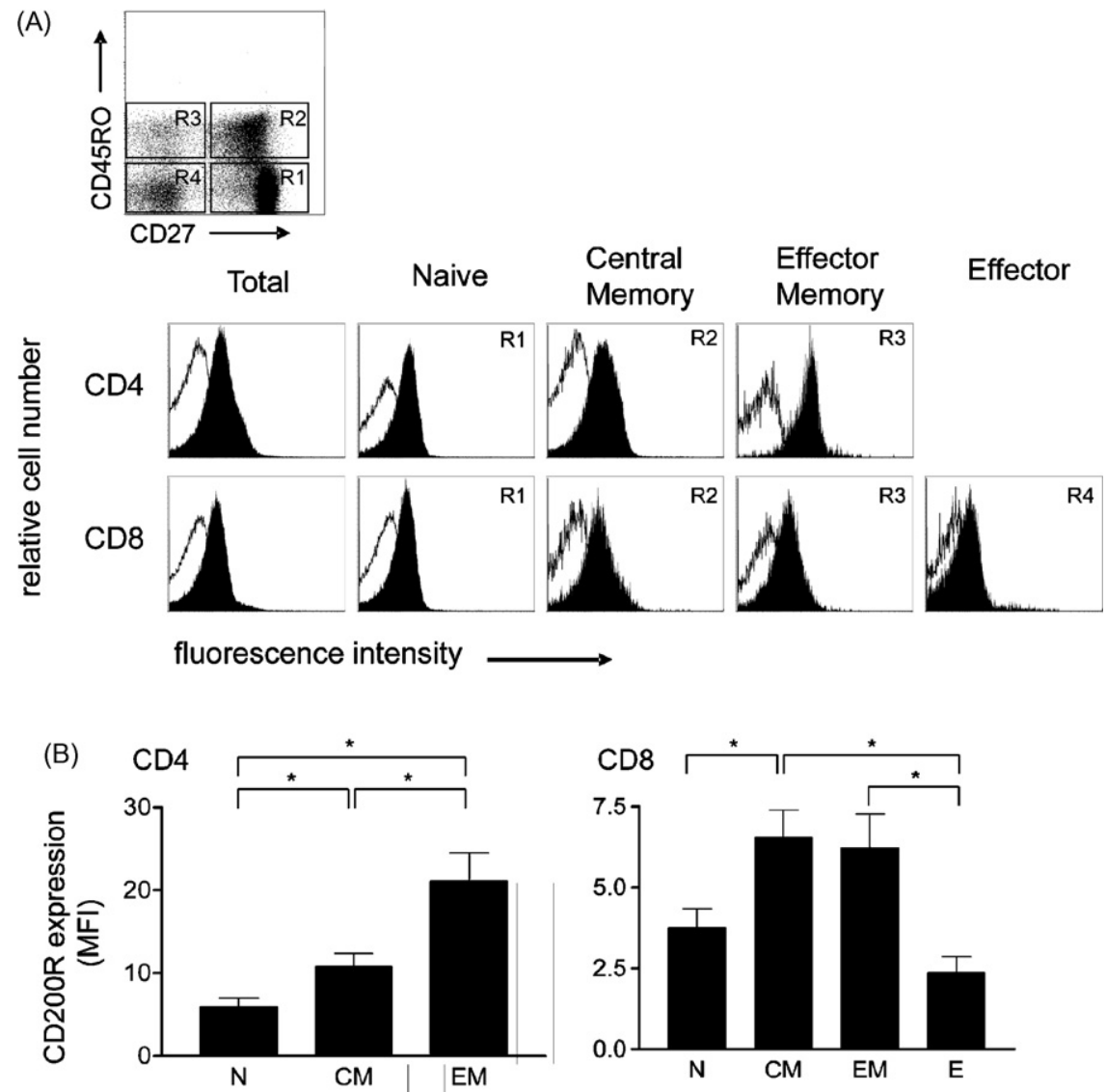

Fig. 2. CD200R is differentially expressed on T-cell subsets. (A) PBMC from healthy volunteers were isolated using Ficoll. Subsets were determined by staining with CD27 and CD45RO as follows: $\mathrm{CD} 27^{+} \mathrm{CD} 45 \mathrm{RO}^{-}$, naïve $(\mathrm{N}) \mathrm{T}$ cells; $\mathrm{CD} 27^{+} \mathrm{CD}^{2} 4 \mathrm{RO}^{+}$, central memory $(\mathrm{CM}) \mathrm{T}$ cells; $\mathrm{CD}^{-} 7^{-} \mathrm{CD} 45 \mathrm{RO}^{+}$, effector memory (EM) $\mathrm{T}$ cells and $\mathrm{CD}_{2} 7^{-} \mathrm{CD}_{4} \mathrm{RO}^{-}$, effector (E) $\mathrm{T}$ cells, as is also indicated for $\mathrm{CD} 3+\mathrm{CD} 8+$ cells in the top panel. Histograms shown are representative of 11 donors analysed in 5 independent experiments, with open histograms representing isotype control staining and filled histograms representing CD200R staining. (B) Averages of the geometric mean fluorescence intensity of CD200R staining of 11 donors analyzed in 5 independent experiments with standard error of the mean (S.E.M.). Left panel, CD200R on CD4 ${ }^{+}$T-cell subsets; right panel, CD200R expression on CD8 ${ }^{+}$T-cell subsets. *Significant, $p<0.05$.

$\mathrm{CD} 27^{-} \mathrm{CD}^{2} 5 \mathrm{RO}^{-}$, effector $(\mathrm{E}) \mathrm{T}$ cells in both $\mathrm{CD} 4^{+}$and $\mathrm{CD} 8^{+}$ T cells (Hamann et al., 1997; Sallusto et al., 1999). In agreement with previous data (Wright et al., 2003), we found higher CD200R expression on $\mathrm{CD}^{+} \mathrm{T}$ cells as compared to $\mathrm{CD} 8^{+}$ $\mathrm{T}$ cells (Fig. 2A), and CD200R was differentially expressed on T-cell subsets (Fig. 2B). Although differences were small, CD200R expression was reproducibly higher on $\mathrm{CD}^{+}$effector memory cells as compared to naïve and central memory
$\mathrm{CD}^{+}{ }^{+} \mathrm{T}$ cells, and $\mathrm{CD} 200 \mathrm{R}$ expression on $\mathrm{CD} 8^{+}$memory subsets was higher than on $\mathrm{CD}^{+}$naïve and effector cells. The effector $\mathrm{CD} 4^{+} \mathrm{T}$-cell population in healthy subjects is too small to be reliably phenotyped. In mice, as in humans, CD200R was expressed higher on $\mathrm{CD}^{+}$splenic $\mathrm{T}$ lymphocytes compared to $\mathrm{CD} 8^{+}$cells and $\mathrm{CD} 44^{+} \mathrm{CD} 62 \mathrm{~L}^{+}$memory $\mathrm{CD} 4^{+} \mathrm{T}$ cells reproducibly expressed the highest levels of CD200R (data not shown).
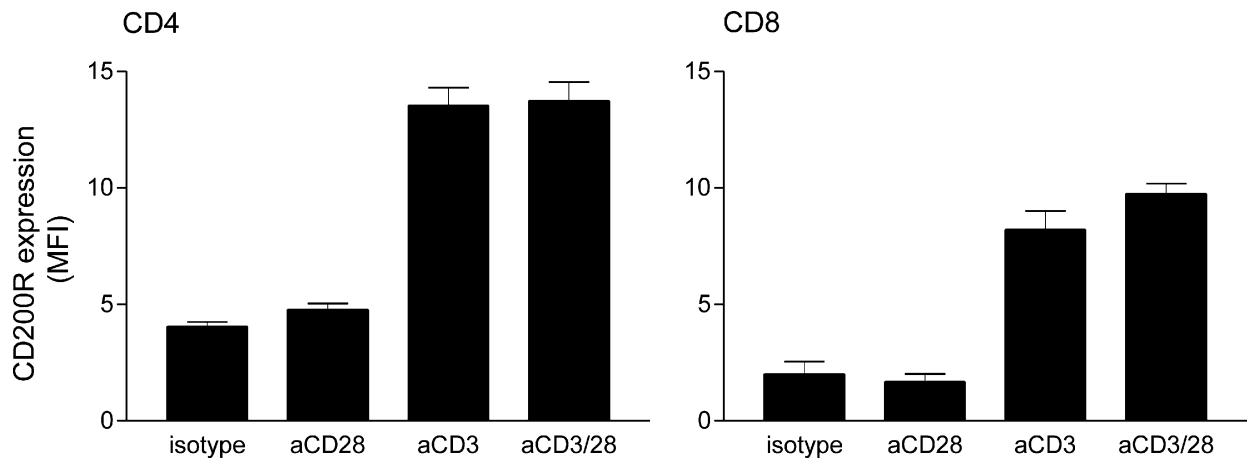

Fig. 3. CD200R expression is up-regulated on T cells stimulated in vitro. PBMC were stimulated with plate-bound $\alpha \mathrm{CD} 3$ and/or $\alpha \mathrm{CD} 28$ for 4 days and analysed with $\alpha \mathrm{CD} 3, \alpha \mathrm{CD} 4$ and $\alpha \mathrm{CD} 8$ antibodies. Averages of the geometric mean fluorescence intensity of CD200R staining analyzed in three independent experiments are shown with standard error of the mean (S.E.M.). 

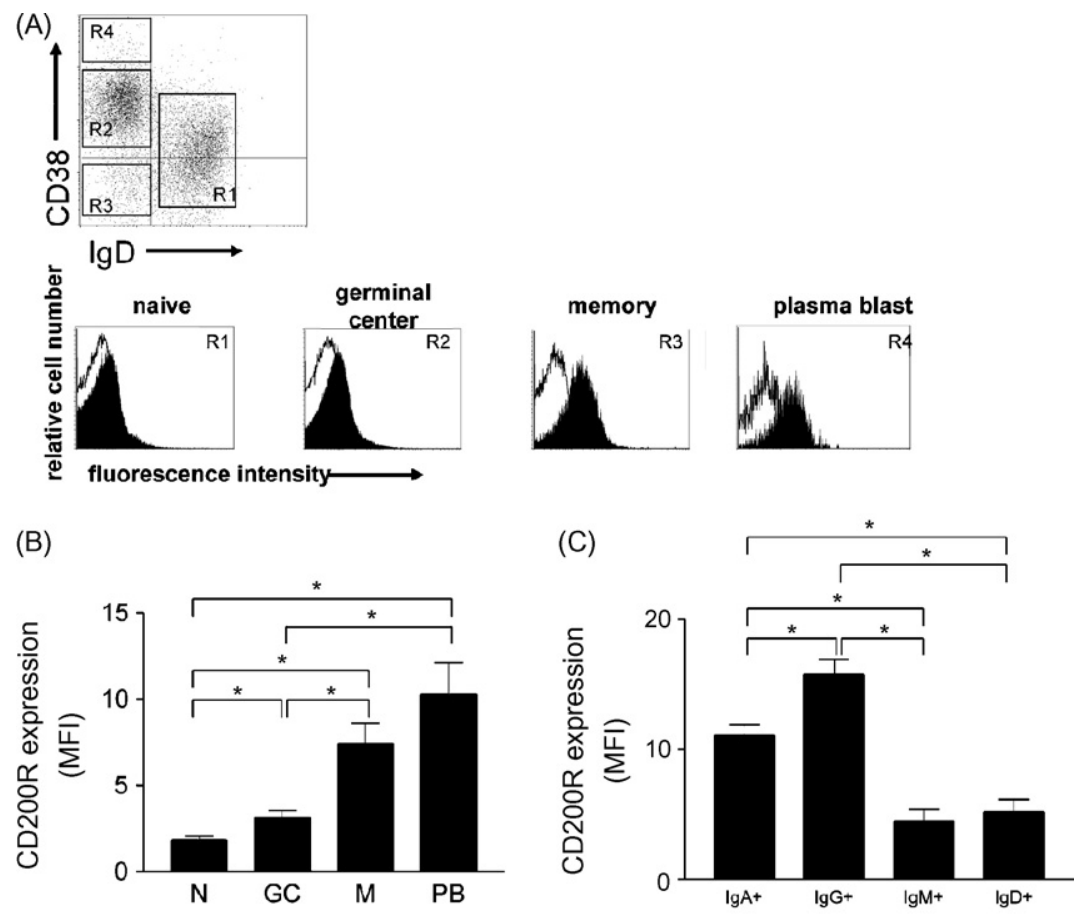

(D)
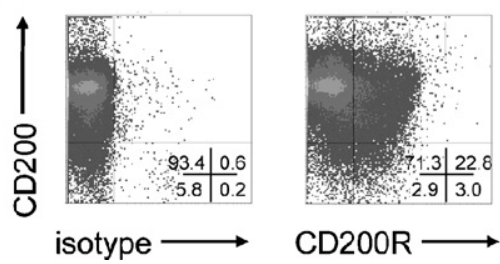

Fig. 4. CD200R is differentially expressed on human tonsillar B-cell subsets. Human tonsils were rest material from adenotomies and/or tonsillectomies. Cells were isolated by forcing them through nylon cell strainers and then stained using the appropriate antibodies. B-cell subsets were determined as follows: $\mathrm{CD}^{+} 9^{+} \mathrm{IgD}{ }^{+}$ naïve (N) tonsillar B cells, CD19 ${ }^{+} \mathrm{IgD}^{-} \mathrm{CD} 38^{+}$germinal centre (GC) tonsillar B cells, CD19+ $\mathrm{IgD}^{-} \mathrm{CD} 38^{-}$memory $(\mathrm{M})$ tonsillar B cells, and CD19 ${ }^{+} \mathrm{IgD}{ }^{-} \mathrm{CD} 38^{++}$ plasma blast (PB) cells. (A) Histograms shown are representative of eight donors, with open histograms representing isotype control staining and closed histograms representing CD200R staining. (B) Shown are averages of the geometric mean fluorescence intensity of CD200R staining on tonsillar B-cell subsets of eight donors with S.E.M. *Significant, $p<0.05$. (C) Tonsillar B cells were identified by staining with antibodies against CD19, IgA, IgG, IgM and IgD. Averages of the geometric mean fluorescence intensity of CD200R staining on tonsillar B-cell subsets of four donors analysed in two independent experiments with S.E.M. are shown. *Significant, $p<0.05$. (D) Peripheral blood CD19+ B cells were analysed for expression of CD200 and CD200R. Almost all B cells express CD200 and around 20\% co-expresses CD200 and CD200R. Left panel indicates isotype control staining, right panel indicates CD200R staining and the percentage of cells in each quadrant is indicated. Data shown are representative for six donors analysed in three independent experiments.

The regulated expression of CD200R on T-cell subsets is supported by the observation that both on $\mathrm{CD} 4^{+}$and $\mathrm{CD} 8^{+} \mathrm{T}$ cells stimulated in vitro by culture of human PBMC on plate-bound $\alpha \mathrm{CD} 3$ or $\alpha \mathrm{CD} 3$ together with $\alpha \mathrm{CD} 28, \mathrm{CD} 200 \mathrm{R}$ was upregulated after 4 days (Fig. 3). In addition, stimulation of mouse splenocytes by $\alpha \mathrm{CD} 3$ - and $\alpha \mathrm{CD} 28$-induced up-regulation of CD200R on both $\mathrm{CD}^{+}$and $\mathrm{CD} 8^{+} \mathrm{T}$ cells (data not shown).

\subsection{CD200R is differentially expressed on peripheral and tonsillar B-cell subsets}

Once we had found expression of CD200R on peripheral B cells, we sought to determine whether CD200R is differentially expressed on B-cell subsets in peripheral blood. We co-stained $\mathrm{CD} 19^{+}$cells with $\mathrm{CD} 27$ and $\mathrm{CD} 38$, to discriminate

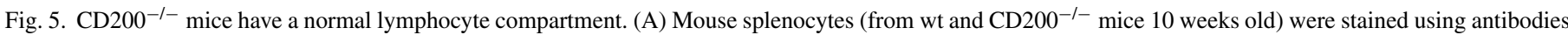

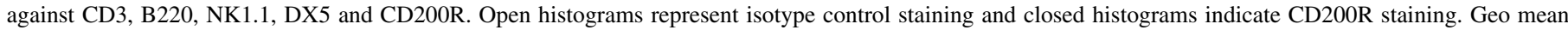

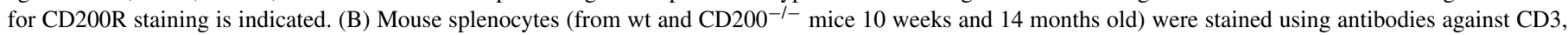

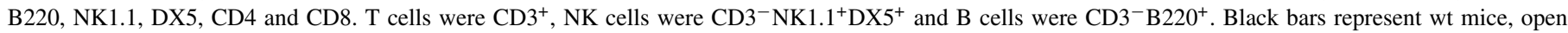

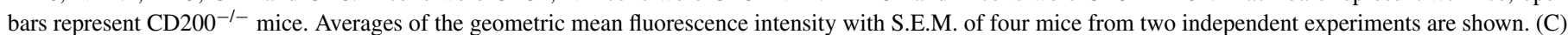

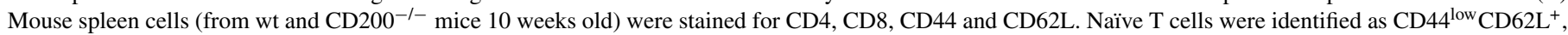

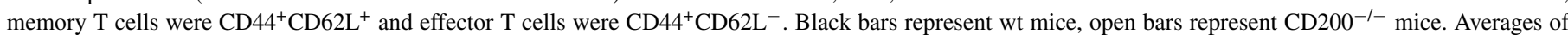

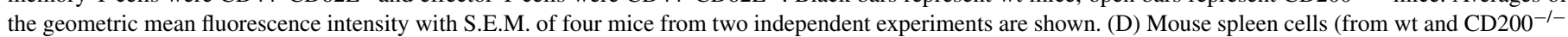

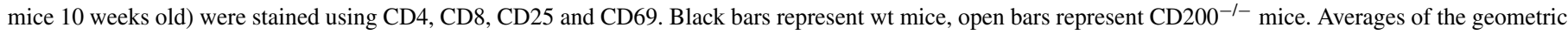
mean fluorescence intensity with S.E.M. of four mice from two independent experiments are shown. 
(A)

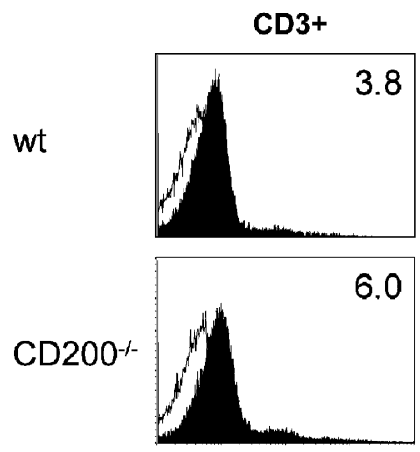

(B)

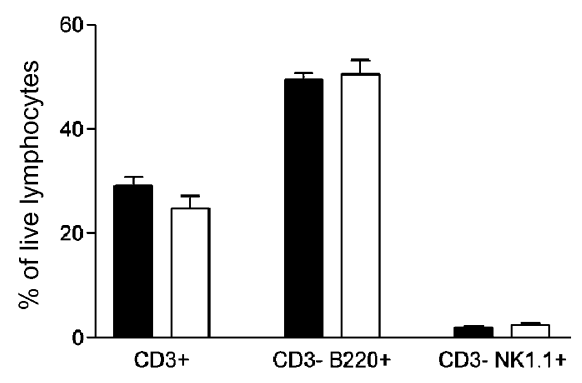

(C)

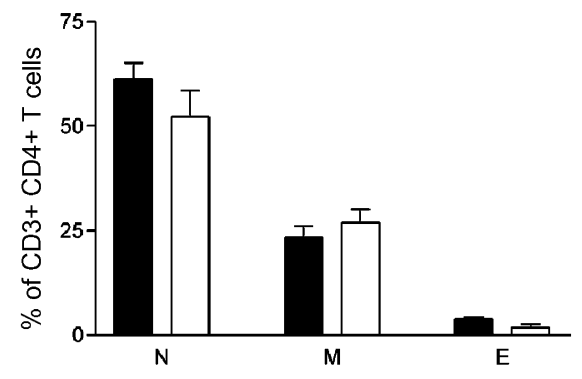

(D)
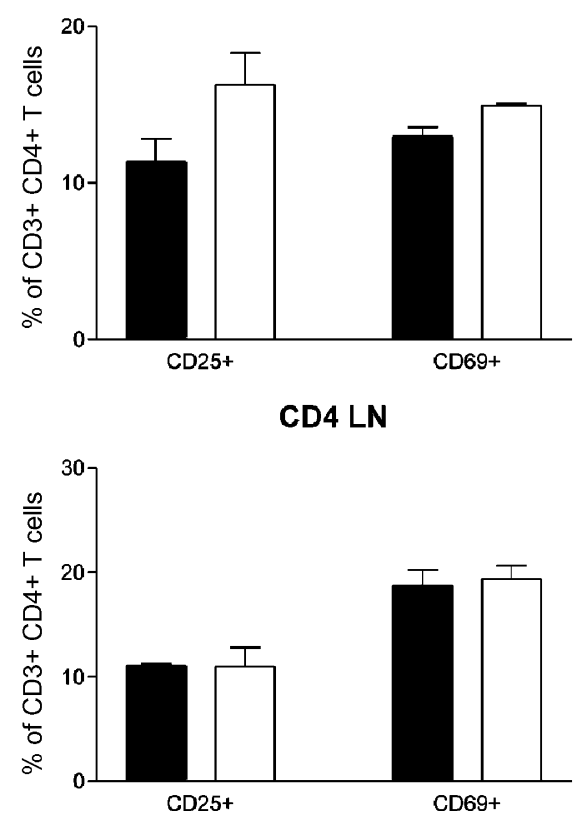

CD3-B220+
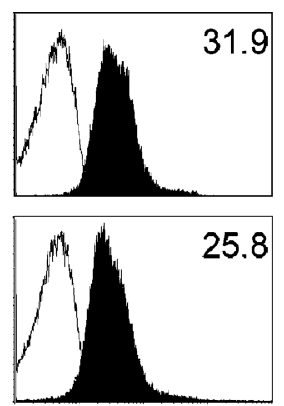

Mice 14 months old

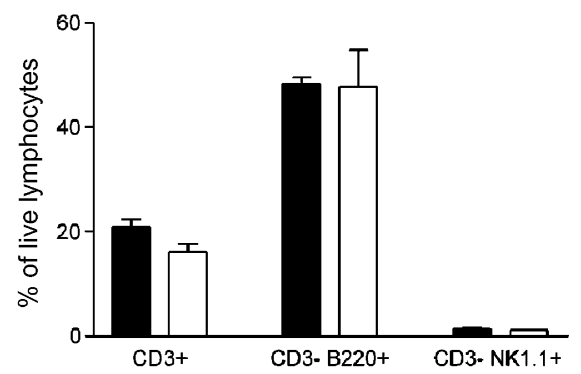

CD8 spleen

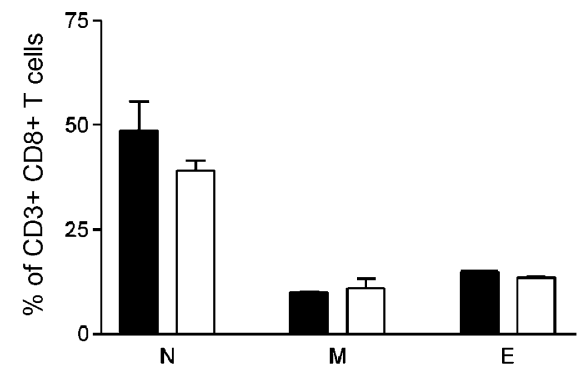

CD8 spleen
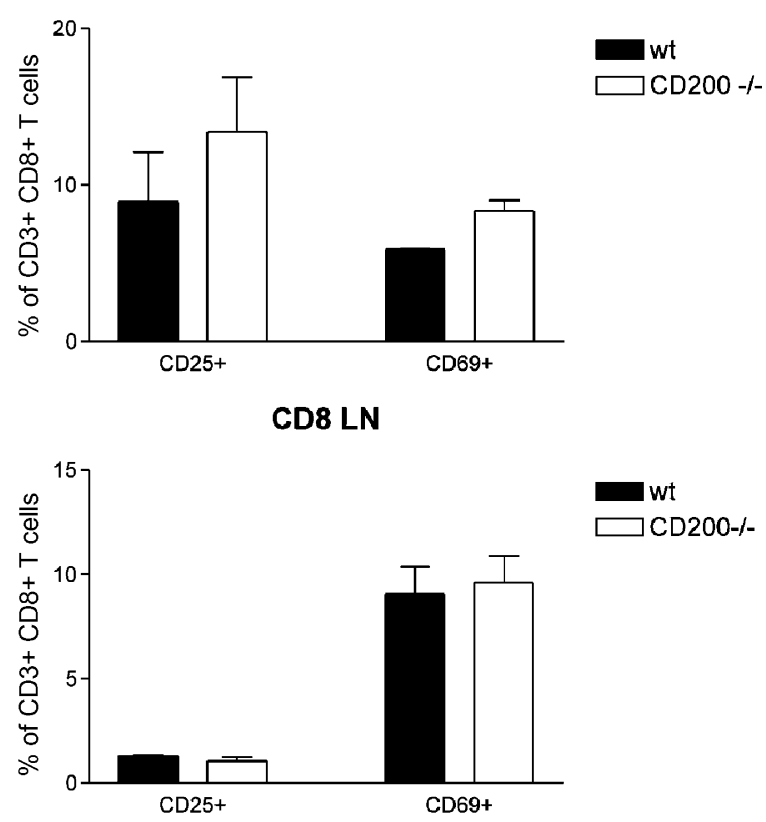
between transitional $\mathrm{CD} 9^{+} \mathrm{CD} 27^{-} \mathrm{CD} 38^{++} \mathrm{B}$ cells (immature $\mathrm{B}$ cells migrating from bone marrow to spleen), naïve $\left(\mathrm{CD} 19^{+} \mathrm{CD} 27^{-} \mathrm{CD}^{-} 8^{-}\right)$and memory $\left(\mathrm{CD} 19^{+} \mathrm{CD} 27^{+} \mathrm{CD} 38^{-}\right)$ $\mathrm{B}$ cells and plasma cells $\left(\mathrm{CD} 19^{+} \mathrm{CD} 27^{+} \mathrm{CD} 38^{++}\right)$(Bhan et al., 1981; Klein et al., 1998). All subpopulations showed detectable CD200R expression, with memory B cells expressing the highest levels of CD200R (data not shown).

To further investigate differential CD200R expression on Bcell subsets in a secondary lymphoid organ, human tonsils were used. We found low but detectable expression of CD200R on total tonsillar B cells. Interestingly, the expression of CD200R on tonsillar B-cell subsets appeared to be regulated during differentiation (Fig. 4A). Naïve (CD19 $\left.{ }^{+} \mathrm{IgD}^{+}, \mathrm{R} 1\right) \mathrm{B}$ cells that have just entered the tonsils expressed low amounts of CD200R. B cells in the germinal centre reaction $\left(\mathrm{CD} 19^{+} \mathrm{IgD}-\mathrm{CD}^{-} 8^{+}, \mathrm{R} 2\right)$ showed slightly increased levels of CD200R expression, whereas B cells that have completed the germinal centre reaction and have differentiated into memory B cells (R3, CD19+ $\left.\operatorname{IgD}^{-} \mathrm{CD} 38^{-}\right)$ or plasma blasts (R4, CD19+ $\mathrm{IgD}^{-} \mathrm{CD} 38^{++}$) showed higher CD200R expression (Fig. 4B). Analysis of CD200R expression on $\mathrm{B}$ cells expressing different $\mathrm{B}$-cell receptors (BCRs) revealed that $\mathrm{CD} 200 \mathrm{R}$ expression was higher on $\mathrm{IgA}^{+}$and especially $\mathrm{IgG}^{+}$B cells compared to $\mathrm{IgM}^{+}$and $\mathrm{IgD}^{+} \mathrm{B}$ cells.

In agreement with previous reports, we find that almost all B cells express CD200. As shown in Fig. 4D, around 20\% of B cells co-express CD200 and CD200R.

\subsection{Absence of CD200-CD200R interaction does not lead to changes in the lymphoid cell compartment in vivo}

We compared the lymphoid compartment of CD200-/- mice with that of wild type control mice to assess whether lack of CD200R triggering on B- and T-cell subsets had direct effects on the composition of these compartments in vivo. CD200R expression in $\mathrm{CD} 200^{-1-}$ animals was similar to that of wild type controls (Fig. 5A). In both young (10 weeks old) and aged (14 months old) mice, no differences were observed in the composition of the splenic lymphoid compartment, both in relative (Fig. 5B) and absolute T-cell, B-cell and NK-cell numbers (data not shown). Further analysis of T-cell subsets in spleen showed that $\mathrm{CD} 200^{-1-}$ mice tended to have less naïve $\mathrm{T}$ cells, although the difference was not significant (Fig. 5C). This difference was not found studying spleens of mice 14 months old and lymph nodes of both young and old mice (data not shown).

To determine whether CD200 ${ }^{-l-}$ mice had a higher fraction of T cells with an activated phenotype in vivo, we also measured the percentage of activated $\mathrm{T}$ cells in spleen and inguinal, axillary and brachial lymph nodes by $\mathrm{CD} 25^{+}$and $\mathrm{CD} 69^{+}$expression. Both young (Fig. 5D) and aged (data not shown) CD200 ${ }^{-1-}$ mice tended to have higher numbers of activated splenic $\mathrm{T}$ cells, although these differences were not statistically significant. Numbers of activated $\mathrm{T}$ cells in lymph nodes were not different between wild type and $\mathrm{CD} 200^{-1-}$ mice (data not shown).

\subsection{Lack of CD200-CD200R interaction has no effect on Ig production in vivo}

Next, the role of CD200R signalling on B cell function in vivo was investigated, by measurement of serum immunoglobulin levels of wild type and CD200 ${ }^{-1-}$ mice. In unchallenged mice, no differences in steady-state serum immunoglobulin levels were observed (data not shown). To measure the antigenspecific immunoglobulin (Ig) production in CD200-/- mice, we challenged mice with T-cell-dependent (TNP-KLH) and T-cellindependent (TNP-Ficoll) antigens. Serum was obtained weekly up to 4 weeks after immunization. The production of specific antibodies by $\mathrm{CD} 200^{-/-}$mice was comparable to that of wild type animals in response to both T-cell-dependent (Fig. 6) and T-cell-independent antigens (data not shown). Thus, the role of CD200R expression on B lymphocytes remains elusive.

\section{Discussion}

Here, we show that expression of the inhibitory immune receptor CD200R is not restricted to cells of the myeloid lineage, but that CD200R is also expressed on human and mouse B and T lymphocytes and NK cells. In addition, CD200R expression is differentially regulated and it is clearly expressed on some T- and B-lymphocyte subsets. For example, CD200R expression is higher on $\mathrm{CD}^{+} \mathrm{T}$ cells than on $\mathrm{CD}^{+} \mathrm{T}$ cells both in mice and humans, indicating differential regulation. This could fit with the observation that $\mathrm{CD} 4^{+} \mathrm{T}$ cells have a higher endogenous threshold of activation than $\mathrm{CD}^{+} \mathrm{T}$ cells: higher concentrations of antigen, longer exposure times or more co-stimulatory signals are needed for activation of $\mathrm{CD}^{+}{ }^{+} \mathrm{T}$ cells (Kaech et al., 2002). This may be influenced by higher expression of CD200R on $\mathrm{CD}^{+}{ }^{+} \mathrm{T}$ cells compared to $\mathrm{CD} 8^{+} \mathrm{T}$ cells, resulting in a stronger inhibitory signal in these cells and hence a higher threshold for activation.

Interestingly, different inhibitory receptors may have distinct effects on the immune system. The expression pattern of CD200R on peripheral T-cell subsets differs from the expression pattern of other inhibitory receptors like LAIR-1 (Maasho et al., 2005; Jansen et al., 2007) and KLRG1 (Robbins et al., 2003). This finding highlights the non-redundant role different inhibitory immune receptors play in the regulation of immune cells and suggests that, depending on the context, cellular activation signals are modulated by specific inhibitory immune receptors. The exact mechanism of lymphoid cell regulation by different inhibitory receptors remains to be investigated.

We report clear CD200R expression on both human and mouse B cells. In addition, we show that CD200R expression is differentially regulated on human peripheral blood and tonsillar B-cell subsets, suggesting a functional role for CD200R in B-cell regulation. This finding is surprising since almost all B cells express high levels of the ligand for CD200R, CD200. We now identify a subpopulation of B cells that expresses both CD200 and CD200R. This could have important implications for the regulation of the activity of these cells, especially in locations where B cells are in close proximity, for example tonsils. CD200R expression was highest on terminally differentiated B 
$\lg M$

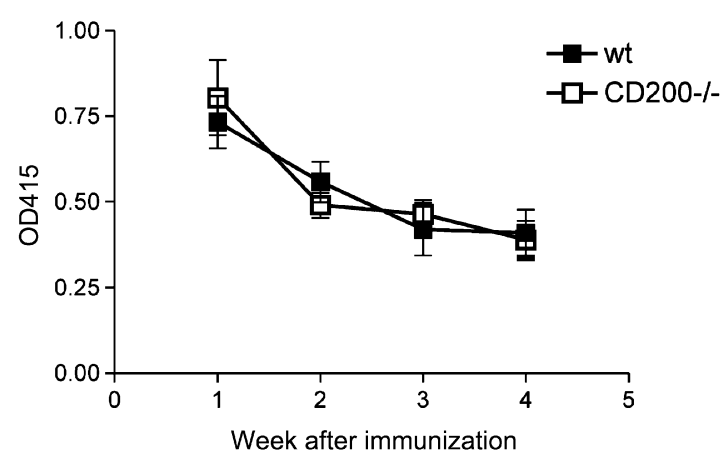

IgG2a

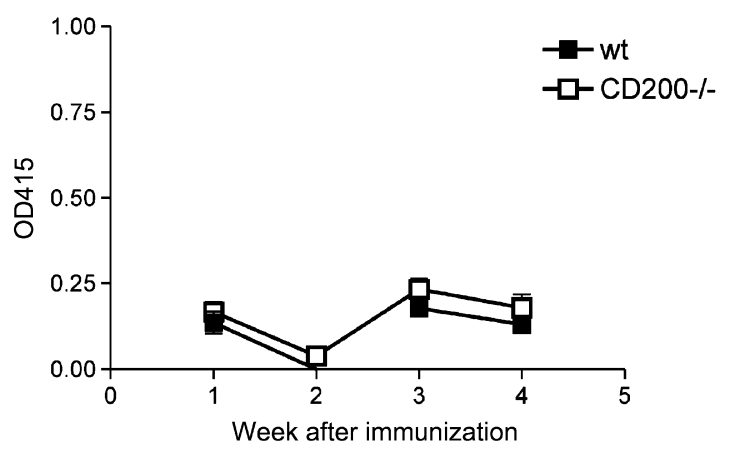

$\lg$ G3

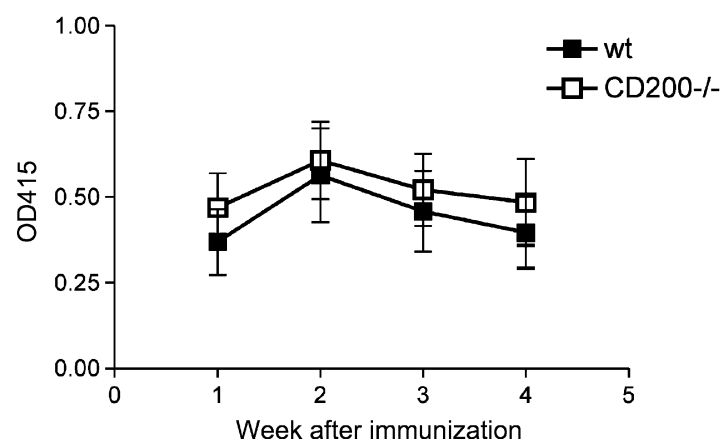

$\lg \mathbf{1} 1$

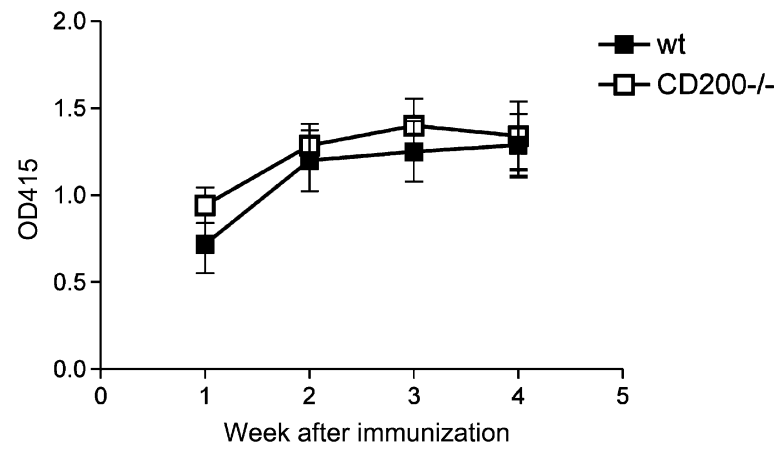

$\lg \mathbf{g} \mathbf{b}$

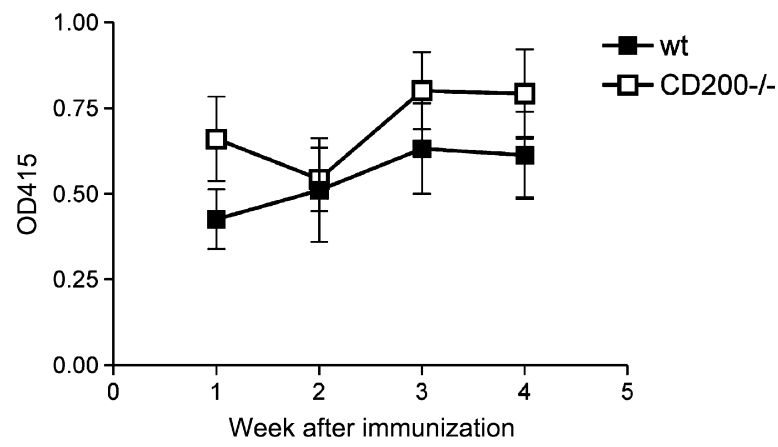

Fig. 6. CD $200^{-1-}$ mice have normal antibody responses. Wild type and $\mathrm{CD} 200^{-1-}$ mice were injected with TNP-KLH. After immunisation, serum was collected weekly and anti-TNP antibody titre determined using isotype-specific ELISA. Depicted are the mean $\mathrm{OD}_{415}$ values of each isotype tested (indicated at the top of the panels) at each time point of five mice per group.

cells: memory B cells and plasma cells in peripheral blood, memory cells and plasmablasts in tonsils. This could indicate that CD200R is not involved in setting a threshold of activation for naïve $B$ cells, but rather in preventing reactivation of memory or effector B cells. The fact that clear CD200R expression has not been reported on B cells earlier (Wright et al., 2003) might be due to variation of CD200R expression levels between different donors and mouse strains, and/or variation in the antibodies used.

The clear and differentially regulated expression of CD200R on some lymphocyte subsets, and the fact that this expression increases upon lymphocyte activation, together have the interesting implication that CD200R not only has a role as regulator of myeloid cells but is also involved in the regulation of the function of lymphocyte subsets. Earlier studies showed that the auto- immune diseases experimental auto-immune encephalomyelitis (EAE) and collagen-induces arthritis (CIA) can be induced more easily in $\mathrm{CD} 200^{-1-}$ mice than in wild type mice (Hoek et al., 2000). Although this phenomenon has previously been attributed to myeloid cells, lymphocytes also are involved in the development of these auto-immune diseases (Corthay et al., 1999; Sospedra and Martin, 2005). The current finding that CD200R is clearly expressed on some lymphocyte subsets, and upregulated after stimulation, might indicate that lack of CD200R signalling in lymphocytes is also involved in development of auto-immunity in $\mathrm{CD} 200^{-/-}$mice.

Previously, CD200R expression was reported on $\mathrm{CD} 4^{+}$ $\mathrm{T}$ cells and triggering of $\mathrm{CD} 200 \mathrm{R}$ on PBMC resulted in monocyte-mediated inhibition of tetanus toxoid-induced cytokine responses (Jenmalm et al., 2006). On dendritic epi- 
dermal T cells, CD200R crosslinking inhibited $\alpha \mathrm{CD} 3$-induced proliferation and cytokine secretion (Rosenblum et al., 2005). Recent findings indicate that CD200 expression is up-regulated on leukaemias (Moreaux et al., 2006; Tonks et al., 2007; McWhirter et al., 2006). In addition, blockade of the interaction between CD200 on leukaemic B cells and CD200R on PBMC was found to inhibit tumour growth in an in vivo model of tumour rejection (Kretz-Rommel et al., 2007). Although the cell type responsible for tumour rejection has not been identified, these data suggest an important role for CD200R signalling in regulation of mononuclear cell effector functions. Our experiments so far have not yet elucidated a prominent role for CD200R in the regulation of the lymphocyte subsets. CD200 ${ }^{-1-}$ mice do not produce different amounts of specific antibodies in response to immunization with T-cell-dependent and T-cell-independent antigens. However, we show that spleens of CD200 $20^{-/-}$mice tend to contain less naïve and more activated $\mathrm{CD} 25^{+}$and $\mathrm{CD} 69^{+} \mathrm{T}$ cells, suggesting increased T-cell activation. The fact that observed differences in vivo are small may be explained by the previous observation that $\mathrm{CD} 200^{-1-}$ do not show a clear phenotype until severely challenged (Hoek et al., 2000). In addition, we cannot exclude that, in $\mathrm{CD} 200^{-1-}$ mice, CD200R might bind another ligand. To further investigate the functional role of CD200R expression on lymphocyte subsets studies with $\mathrm{CD} 200 \mathrm{R}^{-1-}$ mice are required, comparing the outcome of a range of stimuli that specifically activate lymphocytes in $\mathrm{CD} 200^{-/-}$or $\mathrm{CD} 200 \mathrm{R}^{-1-}$ mice.

In summary, we have shown that CD200R is not only expressed on cells of the myeloid lineage, but is also expressed on human and mouse T-lymphocyte subsets. We report regulated expression of CD200R on B-lymphocyte subsets, revealing a B-cell subpopulation that expresses both CD200 and CD200R. Although CD200R signalling is not prominently involved in the development of the lymphoid compartment and B-cell responses to immunization, its regulated expression pattern could indicate a much broader role for CD200R signalling in the regulation of the immune balance than previously anticipated.

\section{Acknowledgements}

This study was supported by grant 015.001 .070 from the Dutch Organisation for Scientific Research (NWO). The authors wish to thank Dr. Anne Schilder for cooperation in obtaining human tonsils, and Prof. Frank Miedema and Drs. Kiki Tesselaar and Christine Jansen for critically reading the manuscript and helpful discussions.

\section{References}

Bhan, A.K., Nadler, L.M., Stashenko, P., McCluskey, R.T., Schlossman, S.F., 1981. Stages of B-cell differentiation in human lymphoid tissue. J. Exp. Med. 154, 737-749.

Bolland, S., Ravetch, J.V., 2000. Spontaneous autoimmune disease in Fc gamma RIIB-deficient mice results from strain-specific epistasis. Immunity 13, 277-285.

Cherwinski, H.M., Murphy, C.A., Joyce, B.L., Bigler, M.E., Song, Y.S., Zurawski, S.M., Moshrefi, M.M., Gorman, D.M., Miller, K.L., Zhang, S., Sedgwick, J.D., Phillips, J.H., 2005. The CD200 receptor is a novel and potent regulator of murine and human mast cell function. J. Immunol. 174, 1348-1356.

Corthay, A., Johansson, A., Vestberg, M., Holmdahl, R., 1999. Collagen-induced arthritis development requires alpha beta $\mathrm{T}$ cells but not gamma delta $\mathrm{T}$ cells: studies with T cell-deficient (TCR mutant) mice. Int. Immunol. 11, 1065-1073.

Hamann, D., Baars, P.A., Rep, M.H.G., Hooibrink, B., Kerkhof-Garde, S.R., Klein, M.R., Van Lier, R.A.W., 1997. Phenotypic and functional separation of memory and effector human $\mathrm{CD}^{+} \mathrm{T}$ cells. J. Exp. Med. 186, $1407-$ 1418.

Hoek, R.M., Ruuls, S.R., Murphy, C.A., Wright, G.J., Goddard, R., Zurawski, S.M., Blom, B., Homola, M.E., Streit, W.J., Brown, M.H., Barclay, A.N., Sedgwick, J.D., 2000. Down-regulation of the macrophage lineage through interaction with OX2 (CD200). Science 290, 1768-1771.

Jansen, C.A., Cruijsen, C., De Ruiter, T., Nanlohy, N., Willems, N., JanssensCorpela, P., Meyaard, L., 2007. Regulated expression of the inhibitory receptor LAIR-1 on human peripheral T cells during T-cell activation and differentiation. Eur. J. Immmunol. 37, 914-924.

Jenmalm, M., Cherwinski, H., Bowman, E., Phillips, J.H., Sedgwick, J.D., 2006. Regulation of myeloid cell function through the CD200 receptor. J. Immunol. 176, 191-199.

Kaech, S.M., Wherry, E.J., Ahmed, R., 2002. Effector and memory T-cell differentiation: implications for vaccine development. Nat. Rev. Immunol. 2, 251-262.

Klein, U., Rajewsky, K., Kuppers, R., 1998. Human immunoglobulin (Ig)M+IgD+ peripheral blood B cells expressing the CD27 cell surface antigen carry somatically mutated variable region genes: $\mathrm{CD} 27$ as a general marker for somatically mutated (memory) B cells. J. Exp. Med. 188, 1679-1689.

Kretz-Rommel, A., Qin, F., Dakappagari, N., Ravey, E.P., McWhirter, J., Oltean, D., Frederickson, S., Maruyama, T., Wild, M.A., Nolan, M.J., Wu, D., Springhorn, J., Bowdish, K.S., 2007. CD200 expression on tumor cells suppresses antitumor immunity: new approaches to cancer immunotherapy. J. Immunol. 178, 5595-5605.

Maasho, K., Masilamani, M., Valas, R., Basu, S., Coligan, J.E., Borrego, F., 2005. The inhibitory leukocyte-associated Ig-like receptor-1 (LAIR-1) is expressed at high levels by human naive T cells and inhibits TCR mediated activation. Mol. Immunol. 42, 1521-1530.

McWhirter, J.R., Kretz-Rommel, A., Saven, A., Maruyama, T., Potter, K.N., Mockridge, C.I., Ravey, E.P., Qin, F., Bowdish, K.S., 2006. Antibodies selected from combinatorial libraries block a tumor antigen that plays a key role in immunomodulation. PNAS 103, 1041-1046.

Moreaux, J., Hose, D., Reme, T., Jourdan, E., Hundemer, M., Legouffe, E., Moine, P., Bourin, P., Moos, M., Corre, J., Mohler, T., De Vos, J., Rossi, J.F., Goldschmidt, H., Klein, B., 2006. CD200 is a new prognostic factor in multiple myeloma. Blood 108, 4194-4197.

Pritchard, N.R., Smith, K.G., 2003. B-cell inhibitory receptors and autoimmunity. Immunology 108, 263-273.

Ravetch, J.V., Lanier, L.L., 2000. Immune inhibitory receptors. Science 290, $84-89$.

Robbins, S.H., Terrizzi, S.C., Sydora, B.C., Mikayama, T., Brossay, L., 2003. Differential regulation of killer cell lectin-like receptor G1 expression on T cells. J. Immunol. 170, 5876-5885.

Rosenblum, M.D., Woodliff, J.E., Madsen, N.A., McOlash, L.J., Keller, M.R., Truitt, R.L., 2005. Characterization of CD200-receptor expression in the murine epidermis. J. Invest. Dermatol. 125, 1130-1138.

Sallusto, F., Lenig, D., Forster, R., Lipp, M., Lanzavecchia, A., 1999. Two subsets of memory $\mathrm{T}$ lymphocytes with distinct homing potentials and effector functions. Nature 401, 708-712.

Sospedra, M., Martin, R., 2005. Immunology of multiple sclerosis. Annu. Rev. Immunol. 23, 683-747.

Takai, T., Ono, M., Hikida, M., Ohmori, H., Ravetch, J.V., 1996. Augmented humoral and anaphylactic responses in Fc gamma RII-deficient mice. Nature 379, 346-349.

Taylor, N., McConachie, K., Calder, C., Dawson, R., Dick, A., Sedgwick, J.D., Liversidge, J., 2005. Enhanced tolerance to autoimmune uveitis in CD200deficient mice correlates with a pronounced $\mathrm{Th} 2 \mathrm{switch}$ in response to antigen challenge. J. Immunol. 174, 143-154. 
Tonks, A., Hills, R., White, P., Rosie, B., Mills, K.I., Burnett, A.K., Darley, R.L., 2007. CD200 as a prognostic factor in acute myeloid leukaemia. Leukemia 21, 566-568.

Wright, G.J., Puklavec, M.J., Willis, A.C., Hoek, R.M., Sedgwick, J.D., Brown, M.H., Barclay, A.N., 2000. Lymphoid/neuronal cell surface OX2 glycoprotein recognizes a novel receptor on macrophages implicated in the control of their function. Immunity 13, 233-242.

Wright, G.J., Cherwinski, H., Foster-Cuevas, M., Brooke, G., Puklavec, M.J., Bigler, M., Song, Y., Jenmalm, M., Gorman, D., McClanahan, T., Liu, M.R.,
Brown, M.H., Sedgwick, J.D., Phillips, J.H., Barclay, A.N., 2003. Characterization of the CD200 receptor family in mice and humans and their interactions with CD200. J. Immunol. 171, 3034-3046.

Zhang, S., Phillips, J.H., 2005. Identification of tyrosine residues crucial for CD200R-mediated inhibition of mast cell activation. J. Leukoc. Biol. 79, 363-368.

Zhang, S., Cherwinski, H., Sedgwick, J.D., Phillips, J.H., 2004. Molecular mechanisms of CD200 inhibition of mast cell activation. J. Immunol. 173, 6786-6793. 